\title{
A STUDY ON THE COMPANY VALUE OF PUBLIC BANKS LISTED IN THE INDONESIAN STOCK EXCHANGE BETWEEN 2010-2015
}

\author{
Atok Muhajir ${ }^{1}$, Miyasto $^{2}$, Wisnu Mawardi ${ }^{3}$ \\ ${ }^{1}$ Master of Management, Economics and Business Faculty of Diponegoro University \\ ${ }^{2}$ Master of Management, Economics and Business Faculty of Diponegoro University \\ ${ }^{3}$ Master of Management, Economics and Business Faculty of Diponegoro University
}

\begin{abstract}
Company value that tends to decline is a problem that must be addressed. This is in line with the theory of company which mentions that the goal of a company is to maximize it value. This study is aimed at analyzing the effects of Loan to Deposit Ratio (LDR), Non-Performing Loan (NPL), Income Diversification and Operational Cost and Return (BOPO) on company value, with Price Book Value (PBV) and Return on Asset (ROA) as intervening variables.

The study population consists of companies listed on the Indonesian Stock Exchange between 2010 and 2015. The sampling technique employed was purposive sampling and 26 companies were sampled according to the pre-determined criteria. Analyzes were carried out using the SPSS program, with the data undergoing a statistical testing beforehand.

Results from the first regression model show that LDR has positive and significant effect on ROA, BOPO has negative and significant effect on ROA, while NPL and Income Diversification does not have any effect on ROA. On the other hand, results from the second regression model show that $L D R$ has a negative and significant effect on PBV; Income Diversification has a positive and significant effect on PBV, whereas NPL and BOPO do not have any effect on PBV. Statistically, this study also shows that ROA has a mediating effect on the relationship between Income Diversification and BOPO against $P B V$.
\end{abstract}

Key Words : LDR, NPL, Income Diversification, BOPO, ROA, PBV

\section{INTRODUCTION}

The main goal a company wishes to achieve is maximizing its value as to attract investors to invest in the company. A company's value is measured from its market value that is the value of its share at the end of a fiscal year (Chen et al, 2011). Company value is also a measure of its management success in business operation both in the past and for the coming prospects in order to convince investors (Chandra, 2007).

Company value in this research is approximated using the Price Book Value (PBV). This PBV proxy is used as this ratio is commonly employed by investment managers and investors in determining share value (Pandey, 2005). PBV value reflects investors' perception against a company, in terms of management quality, profitability, liquidity, and prospect (Reilly and Brown, 1997). PBV is the proxy of company value that is stable and simple that can readily compared to either the market value or a similar company in order to determine whether a share is cheap or expensive (Marangu and Jagongo, 2014).

One of the aspects that affect company value is profitability. This is because 
profitability is the ratio between gain and the total asset and is a measure of a company's success. High profitability gives positive signals to the market and provides value for the company. A company's performance can be measured using profitability ratio that is its Return on Asset (ROA), which is the best measuring instrument for performance (Dod and Chen, 1966). Hence, profitability is a measure of financial performance that compares gain to investment.
This research explains the phenomenon of gap that takes place as there is a decreasing tendency of PBV and financial ratios of Loan Deposit Ratio (LDR), NonPerforming Loan (NPL), Income diversification, Operational Cost against Operational Gain (BOPO), and Return on Asset (ROA) that are not consistent each year. Data of this gap phenomenon from each of those variables are given in Table 1 as follows:

Table 1

Mean LDR, NPL, Income Diversification, BOPO, ROA, PBV from 31 Public Banks listed in BEI for the 2010-2015 period

\begin{tabular}{cccccccc}
\hline Ratio & $\mathbf{2 0 1 0}$ & $\mathbf{2 0 1 1}$ & $\mathbf{2 0 1 2}$ & $\mathbf{2 0 1 3}$ & $\mathbf{2 0 1 4}$ & $\mathbf{2 0 1 5}$ & $\mathbf{2 0 1 6}$ \\
\hline LDR & 74,78 & 74,49 & 77,71 & 82,18 & 88,22 & 85,59 & 80,49 \\
\hline NPL & 4,17 & 4,92 & 2,45 & 2,33 & 2,15 & 2,63 & 3,11 \\
\hline $\begin{array}{c}\text { Income } \\
\text { Diversification }\end{array}$ & 1,16 & 1,12 & 1,04 & 1,04 & 1,10 & 0,95 & 1,07 \\
\hline BOPO & 86,27 & 85,63 & 84,04 & 81,44 & 83,28 & 86,67 & 84,56 \\
\hline ROA & 1,46 & 1,53 & 1,86 & 2,13 & 1,88 & 1,42 & 1,71 \\
\hline PBV & 2,52 & 1,83 & 3,06 & 2,14 & 2,43 & 1,27 & 2,21 \\
\hline
\end{tabular}

Research on liquidity ratio or LDR against profitability results in significantly positive influence as stated by Boadi et al. (2015) and Arif (2012), while it is also found to have significantly negative effect as mentioned by Almazari (2014) and Yamuna (2013). Research on non-performing loan or NPL against profitability shows significantly negative influence as described by Arif (2012), Malik (2015), and Chiou et al (2014) Rodriguez (2014), whereas it is also found as to have no effect on profitability whatsoever by Jha and Hui (2012). Research on income ratio other than interest or income diversification against profitability indicates significantly positive influence as recorded by Sawada (2013), Bhatia et al. (2012), Alper and Albar (2011), Rodriguez (2014) and Chiou et al (2014), while Wang et al. (2015) and Afza et al. (2008) found no effect of this measure on profitability. Research on operational cost efficiency shows significantly negative effect as found by Bhatia et al. (2012), Almazari (2014) and Maredza (2014), whereas Rodriguez (2014) and Karim and Alam (2013), found no effect.

Research on liquidity ratio against company value reveals significantly positive effect as discovered by Repi et al. (2015), Basarn and Ulker (2015), while Shamsudin et al. (2013) and Clercq (2015) mentioned no effect. On the other hand, yet another research by Gharaibeh (2014) and Waleed et al (2016) found significantly negative affect of liquidity ratio against company value. Research on NPL ratio against company value shows significantly negative influence as mentioned by Repi et al (2015), Yao and 
Liang (2005) and Chiou et al (2014), while Putra (2016) and Karim and Alam (2013) stated that NPL does not affect company value. Research on income ratio other than interest or income diversification on company value reveals significantly positive effect as shown by Sawada (2013), Afza et al. (2008), Ardian Prima Putra (2016) and Chiou et al (2014), whereas Laeven and Levine (2005) and Clercq (2015) found no effect. Research on operational cost efficiency against company value shows significantly negative influence as found by Yao and Liang (2005) and Sawada (2013), while Clercq (2015) and Karim and Alam (2013) discovered no effect.

Based on those gap and research gap phenomena, the following questions are formulated:

(1) How does LDR affect ROA?

(2) How does NPL affect ROA?

(3) How does Income Diversification affect ROA?

(4) How does BOPO affect ROA?

(5) What is the effect of LDR against company value?

(6) What is the affect NPL against company value?

(7) What is the effect of Income Diversification against company value?

(8) What is the effect of BOPO against company value?

(9) What is the effect of ROA against company value?

(10) Does ROA mediate the effects of LDR, NPL, Income Diversification, and BOPO against company value?

\section{LITERATURE REVIEW}

\section{Theory}

The signaling theory gives direction to investor on how the management perceives a company's prospect (Brigham and Houston, 2001). Based on this signal theory, a quality company gives signal to the market as to allow the later to respond properly.

The economic efficiency theory aims to measure the performance of a banking system. A bank is said to be efficient when it meets three (3) criteria of; using facilities optimally (technical efficiency), allocating available resources optimally (allocative efficiency), and yielding products at optimum level (scale efficiency) (Coelli et al., 2005). A company is deemed efficient when it can minimize the cost for certain outputs or when it can maximize its profit using the available input combination (Srivastava, 1999).

The intermediation theory states that financial intermediation is based on minimum production cost of information related to intensive problem solving (Schumpter, 1939). There are five (5) types of financial intermediation; denomination intermediation concerning ratio in savings and loan value, risk intermediation related to transformation of credit risk from depositors, due date intermediation concerning due dates for both savings and loan, information intermediation related to information on economic condition, and currency intermediation concerning different values in currencies.

\section{Earlier Research}

Laeven and Levine (2005) conducted a research on the effect of income diversification and macro factors on company value. It was found that income diversification does not affect company value. Yao and Liang (2005) carried out a research on factors affecting the value of banks in Taiwan. They discovered that efficiency and NPL negatively affect company value, while profitability positively affects company value. Afza et al. (2008) tested the effect of income diversification against profitability and company value. They found out that that 
income diversification positively affects profitability and company value. Alper and Albar (2011) measured the effect of internal matters and macro aspects on the profitability of some banks in Turkey. They revealed that income diversification positively affects profitability. Bhatia et al. (2012) probed into the effect of internal matters against profitability. They showed that NPL and operational cost efficiency negatively affect profitability, while income diversification positively affects profitability.

Arif (2012) carried out a research on the effect of financial ratio of banks in Pakistan against profitability. He found that liquidity and NPL negatively affect profitability. Jha and Hui (2012) conducted a research on the effect of financial ratio in banks in Nepal against profitability. They found out that NPL and LDR do not affect profitability. Karim and Alam (2013) tested the effect of internal matters on company value. They showed that operational efficiency does not affect ROA and company value, whereas credit risk negatively affects ROA, but it does not affect company value.

Yamuna (2013) measured the effect of internal matters in banks in Srilanka on profitability. She discovered that liquidity positively affects ROA, while overhead cost negatively affects ROA. Shamsudin et al. (2013) analyzed the effect of fundamental maters on company value of banks in Malaysia. He showed that ROA negatively affects company value, while LDR does not affect company value. Sawada (2013) carried out a research on the effect of income diversification and financial risk in banks in Japan on company value. He understood that income diversification positively affects company value, whereas BOPO and NPL negatively affect company value.

Gharaibeh (2014) tested the effect of non-profit ratio on company value. He discovered that liquidity negatively affects company value. Almazari (2014) had a research on the effect of internal matters against profitability in banks in Jordan and Saudi Arabia. He found that BOPO negatively affects ROA, while LDR positively affects ROA. Maredza (2014) probed into the effect of operational cost and internal efficiency on profitability in banks. He showed that total productivity efficiency negatively affects ROA. Chiou et al. (2014) delved into the effect of internal matters on profitability and company value. They figured out that income other than interest positively affects ROA and company value, loan loss contribution negatively affects ROA and company value, while ROA positively affects company value. Rodriguez (2014) tested the effect of internal matters on profitability. He showed that loan to deposit, provision for loan losses, and operating expense do not affect ROA, while non-interest revenue positively affects ROA.

Clercq (2015) managed to test the effect of factors affecting company value in banks in Europe. He showed that profitability positively affects company value, while loan to asset efficiency and income diversification do not affect company value and that credit risk quality negatively affects company value. Wang et al. (2015) carried out a research on the effect of income diversification against profitability and company value in banks in China and the USA. They figured out that income diversification positively affects company value, but it does not affect profitability.

Basarn and Ulker (2015) conducted a research on the effect of internal matters on share prices. They showed that liquidity negatively affects share prices, whereas ROA does not. Malik et al. (2015) tested the effect of internal and external matters on profitability. They found out that NPL negatively affects ROA. Makram et al. (2015) 
delved into the effect of internal and external matters on profitability in banks. They discovered that efficiency negatively affects ROA. Boadi et al. (2015) had a research on the effect of internal and macro aspects on profitability in banks in Ghana. He showed that liquidity management negatively affects ROA.

Repi et al. (2015) tested the effect of profitability and fundamental ratio on company value. They revealed that ROA positively affects PBV, while LDR and NPL negatively affect PBV. Putra (2016) probed into the effect of financial risk in banks against company value. He figured out that ROA and NPL do not affect company value. However, income diversification proved to have positive effect on company value. Waleed et al. (2016) conducted a research on the effect of liquidity on company value in banks in Pakistan. They found that liquidity negatively affects company value.

\section{RESEARCH METHODOLOGY}

\section{Source of Data and Sample}

The data used in this research are secondary data consisting of the financial reports of audited sample companies listed in the Indonesian Stock Exchange (BEI) from 2010 - 2015. These data were taken from the ICMD and also BEI (www.idx.co.id).

Samples for this research were taken using the purposive random sampling method. The criteria included banks that are listed in BEI continuously from 2010 - 2015 and are continuously making gains during that period. These criteria found 26 banks. The other variables included in this research are given in the frame work as shown in Figure 1.

Figure 1

Theoretical Framework

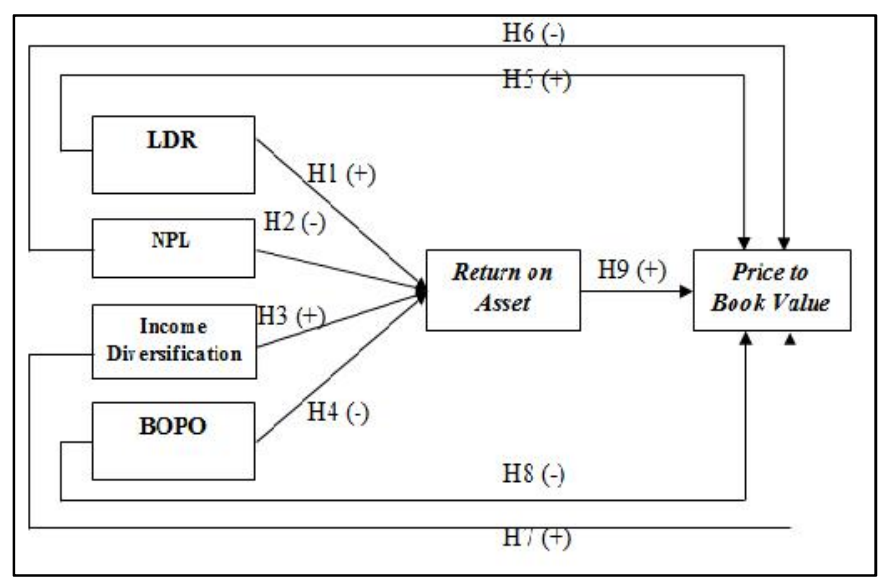

\section{Definition of Operational Variable}

Independent variables are the variables that affect or cause changes in or the emergence of a dependent variable. In this research they are Loan Deposit Ratio, NonPerforming Loan, Income Diversification, and Operational Cost against Operational Income. Dependent variables are variables that are affected or resulted from the presence of independent variables. In this research it is the Price to Book Value. Intervening variables are variables that connect both independent and independent variables. In this case, it is the Return on Asset.

Table 2

Variable and Operational Definition

\begin{tabular}{clllll}
\hline No & Variable & \multicolumn{2}{c}{ Description } & Scale & \multicolumn{2}{c}{ Measurement } \\
\hline 1 & Return on & Ratio between profit & Ratio & ROA $=$ Profit before tax $\times$ \\
& Asset $(\mathrm{ROA})$ & before tax and total & & $100 \%$ \\
\hline
\end{tabular}




\begin{tabular}{|c|c|c|c|c|}
\hline & & asset. & & $\begin{array}{c}\text { Total asset } \\
\text { (Triandaru and Santoso, 2006) }\end{array}$ \\
\hline 2 & $\begin{array}{l}\text { Price Book } \\
\text { Value (PBV) }\end{array}$ & $\begin{array}{l}\text { Comparison between } \\
\text { share price (closing } \\
\text { price at year end) and } \\
\text { book value (equity of } \\
\text { per share) in a } \\
\text { company. }\end{array}$ & Ratio & $\begin{array}{l}\text { PBV }=\underline{\text { Share price }} \times 100 \% \\
\text { Book value } \\
\text { (Tjipto and Fakhruddin, 2001) }\end{array}$ \\
\hline 3 & $\begin{array}{l}\text { Loan to } \\
\text { deposit ratio } \\
\text { (LDR) }\end{array}$ & $\begin{array}{l}\text { Ratio between the } \\
\text { amounts of fund } \\
\text { distributed to the } \\
\text { market in the form of } \\
\text { credit and the amount } \\
\text { of fund from the market } \\
\text { and personal capital } \\
\text { being used. }\end{array}$ & Ratio & LDR $=\frac{\text { Total credit }}{\text { Total DPK }} \times 100 \%$ \\
\hline 4 & $\begin{array}{l}\text { Non- } \\
\text { performing } \\
\text { loan (NPL) }\end{array}$ & $\begin{array}{l}\text { Ratio between the } \\
\text { number of non- } \\
\text { performing loans (non- } \\
\text { liquid loan, and bad } \\
\text { loan) against total } \\
\text { credit. }\end{array}$ & Ratio & $\begin{array}{l}\text { NPL }=\text { Non-performing credit } \times \\
100 \% \\
\text { Total credit } \\
\text { (Triandaru and Santoso, 2006) }\end{array}$ \\
\hline 5 & $\begin{array}{l}\text { Income } \\
\text { Diversification } \\
\text { (DP) }\end{array}$ & $\begin{array}{l}\text { Ratio between the } \\
\text { amount of income other } \\
\text { than interest and total } \\
\text { asset. }\end{array}$ & Ratio & $\begin{array}{l}\mathrm{DP}=\text { Non-interest income } \mathrm{X} \\
100 \% \\
\text { Total asset } \\
(\text { Alper and Albar, 2011) }\end{array}$ \\
\hline 6 & $\begin{array}{l}\text { Operational } \\
\text { cost against } \\
\text { operational } \\
\text { gain (BOPO) }\end{array}$ & $\begin{array}{l}\text { Ratio between the } \\
\text { amount of operational } \\
\text { cost and operational } \\
\text { gain. }\end{array}$ & Ratio & $\begin{aligned} \text { BOPO }= & \frac{\text { Total operational cost }}{\times 100 \% \quad \text { Total }} \\
& \text { operational gain }\end{aligned}$ \\
\hline
\end{tabular}

(Triandaru and Santoso, 2006)

Source: Books and journals

\section{Method of Analysis}

Certain assumptions must be met during linear regression as to ensure a valid result (Ghozali, 2006). These assumptions include normality, autocorrelation, multicolinearity, and heterokedasticity tests. The next step is hypothesis testing with $\mathrm{F}$ and $t$ tests. The model of multiplier linear regression in this research is as follows:

$\mathrm{Y} 1=\mathrm{a} 1+\mathrm{b} 1 \mathrm{X} 1+\mathrm{b} 2 \mathrm{X} 2+\mathrm{b} 3 \mathrm{X} 3+\mathrm{b} 4 \mathrm{X} 4+\mathrm{e} 1$

$\mathrm{Y} 2=\mathrm{a} 2+\mathrm{b} 4 \mathrm{X} 1+\mathrm{b} 5 \mathrm{X} 2+\mathrm{b} 6 \mathrm{X} 3+\mathrm{b} 4 \mathrm{X} 4+$ $\mathrm{b} 7 \mathrm{Y} 1+\mathrm{e} 2$
Mediation test using bootstrapping was also done to figure out the direct effect of the independent variables on the dependent variables and the indirect effect of independent variables when intervening variables were used.

\section{ANALYSIS AND DISCUSSION}

\section{Descriptive Statistics}

Descriptive statistics is aimed at providing general description of the data obtained. The minimum, maximum, mean, 
and standard deviation of research variables are given in Table 3.

Table 3

Result of Descriptive Analysis

\begin{tabular}{lccccc}
\hline & N & Minimum & Maximum & Mean & $\begin{array}{c}\text { Standard } \\
\text { Deviation }\end{array}$ \\
\hline LDR & 156 & 40,22 & 140,72 & 80,0040 & 14,17752 \\
\hline NPL & 156 & 0,21 & 8,82 & 2,1200 & 1,28160 \\
\hline DP & 156 & 0,04 & 3,05 & 1,0533 & 0,69649 \\
\hline BOPO & 156 & 33,28 & 97,97 & 80,5549 & 9,43389 \\
\hline ROA & 156 & 0,18 & 5,15 & 2,1996 & 1,09090 \\
\hline PBV & 156 & 0,30 & 17,11 & 1,7578 & 1,72208 \\
\hline Valid N (listwise) & 156 & & & & \\
\hline Source: analyzed secondary data
\end{tabular}

It can be seen from Table 4.1 that the mean value for PBV of banks listed in BEI for the 20102015 period is 1.7578 with a standard deviation of 1.72208 , which means that the standard deviation for company value (PBV) is less than the mean value. Mean PBV value of more than 1 show that the market value is greater than the value on the book.

Mean ROA for banks listed in BEI for the 2010 - 2015 is 2.1996 with a standard deviation of 1.09090. This means that ROA value fluctuates slightly for banks, as evident with less standard deviation of ROA compared to the mean ROA. This mean ROA indicates that the banks' profitability is in good condition as required by the Bank of Indonesia (BI) to be at least more than $1.5 \%$.

Mean LDR value for banks listed in BEI for the 2010 - 2015 period is 80.0040 with a standard deviation of 14.17752. The lowest LDR value during the research period is at $40.22 \%$, recorded for BVIC bank in 2011. Meanwhile, the highest LDR value is at $140.72 \%$, achieved by SDRA bank in 2014 . This mean LDR value indicates good bank intermediation as required by $\mathrm{BI}$ to be around 78-92\%.
Mean NPL value for banks listen in BEI for the 2010 - 2015 period is 2.1200 with a standard deviation of 1.28160 . The lowest NPL value during the research period is at $0.21 \%$, recorded for BNBA bank in 2014 . Meanwhile, the highest NPL value is at 8.82 $\%$, achieved by AGRO bank in 2011. This mean NPL value shows that credit quality is good and that banks are still able to maintain their credit quality as required by BI to be below $5 \%$.

Mean Income Diversification value for banks listed in BEI for the 2010 - 2015 period is 1.0533 with a standard deviation of 0.69649. The lowest Income Diversification value during the research period is at $0.04 \%$, recorded for INPC bank in 2015. Meanwhile, the highest Income Diversification value is at $3.05 \%$, reached by BVIC bank in 2011. This Income Diversification value indicates that public banks are still conventional in nature, in that they largely depend on interest for their income.

Mean BOPO value for banks listed in BEI for the 2010-2015 period is 80.5549 with a standard deviation of 14.17752. The lowest BOPO value during the research period is at $33.28 \%$, recorded for SDRA bank in 2014. Meanwhile, the highest BOPO value is at 
$97.97 \%$, achieved by BAEK bank in 2015. This mean BOPO value shows that banks are already able to run their operation efficiently as required by BI to be below $92 \%$.

\section{Classic Assumption Test}

Prior to carrying out testing for the hypothesis of this research, the sample of mean financial ratio calculation over the past 6 years must be tested first. This initial test employs the classic assumption that includes: normality, autocorrelation, multicolinearity, and heterokedasticity.

Normality test must be carried out as the data should be normally distributed. Normal data are indicated with Kolmogorov Smirnov test value with more than 0.05 significance. Results of Kolmogorov Smirnov tests for the first sig. model is $0.041>0.05$ and for the second sig. Model it is $0.397>$ 0.05 . Therefore, the data in this research are considered normal.

Heterokedasticity test is conducted using the park test by the regression of the residual squared algorithmic value (LnU2i) against the independent variables. If independent variables significantly affecting dependent variables, then a heterokedasticity is indicated. Should this significant probability is above the $5 \%$ trust level, then it can be concluded that the regression model does not contain any heterokedasticity (Ghozali, 2006). Results of the park test for the first and second sig. Model are $>0.05$. This means that the data in this research are free from heterokedasticity.

Multicolinearity test is done by paying attention to the Variance Inflation Factor
(VIF) and Tolerance values from regression output. VIF value of greater 10 or Tolerance value of lower than 0.1 show that there is a problem of multi-co-linearity in the regression model. The VIF and Tolerance value for both models is more than 10 and lower than 0.1 respectively. Therefore the regression model here is free from the problem of multicolinearity.

Deviation in autocorrelation in this research is tested using the run test. This run test is aimed at knowing whether the linear model includes a correlation between disturbance error at period $t$ and at period $t$ 1 (earlier period). Results of run test for the first sig. Model is $0.184>0.05$ and for the second sig. Model is $0.068>0.05$. Therefore, the data of the data of this research is said to be random.

\section{Multiplier Regression Analysis}

Determination coefficient values state the percentage of dependent variables that can be explained with independent variables. Determination coefficient values are known from the values of adjusted $\mathrm{R}^{2}$. For first model with ROA as dependent variable, the value of adjusted $\mathrm{R}^{2}$ in the regression model is 0.719 . This means that $71.9 \%$ of ROA variables are affected by the four variables of LDR, NPL, Income Diversification, and BOPO, while the remaining variables $(28.1 \%)$ are not yet covered by this research.

Based on results of SPSS output, it can be seen that the partial effects the four independent variables have on ROA can be summarized as shown in Table 4. 


\section{Table 4}

Result of The First $t$ Model Test

\begin{tabular}{lccccccc}
\hline & \multicolumn{2}{c}{$\begin{array}{c}\text { Unstandardized } \\
\text { Coefficients }\end{array}$} & $\begin{array}{c}\text { Standardized } \\
\text { Coefficients }\end{array}$ & & & \multicolumn{2}{c}{$\begin{array}{c}\text { Collinierity } \\
\text { Statistics }\end{array}$} \\
\cline { 2 - 4 } Model & B & Std. Error & Beta & t & Sig. & Tolerance & VIF \\
\hline Constant & 6,347 & 0,483 & & 13,130 & 0,000 & & \\
\hline LDR & 0,258 & 0,114 & 0,102 & 2,259 & 0,025 & 0,943 & 1,060 \\
\hline NPL & $-0,43$ & 0,034 & $-0,063$ & $-1,268$ & 0,207 & 0,796 & 1,256 \\
\hline DP & 0,041 & 0,034 & 0,062 & 1,200 & 0,232 & 0,715 & 1,398 \\
\hline BOPO & $-3,426$ & 0,217 & $-0,806$ & $-15,798$ & 0,000 & 0,744 & 1,344 \\
\hline
\end{tabular}

Source: analyzed secondary data

From Table 4, the following multiplier linear regression equation can be formulated: $\mathrm{ROA}=6.347+0.258 \mathrm{LDR}-0.043 \mathrm{NPL}+$ $0.041 \mathrm{DP}-3.426 \mathrm{BOPO}+e$

Determination coefficient values state the percentage of dependent variables that can be explained with independent variables. Determination coefficient values are known from the values of adjusted $\mathrm{R}^{2}$.

For second model with PBV as dependent variable, the value of adjusted $R^{2}$ in the regression model is 0.360 . This means that $36 \%$ of PBV variables are affected by the four variables of LDR, NPL, Income Diversification, BOPO, and ROA, while the remaining variables (64\%) are not yet covered by this research.

Based on results of SPSS output, it can be seen that the partial effects the five independent variables have on PBV can be summarized as shown in Table 5.

Table 5

Result of The Second $t$ Model Test

\begin{tabular}{|c|c|c|c|c|c|c|c|}
\hline \multirow[b]{2}{*}{ Model } & \multicolumn{2}{|c|}{$\begin{array}{c}\text { Unstandardized } \\
\text { Coefficients }\end{array}$} & \multirow{2}{*}{$\begin{array}{c}\text { Standardized } \\
\text { Coefficients } \\
\text { Beta } \\
\end{array}$} & \multirow[b]{2}{*}{$\mathbf{t}$} & \multirow[b]{2}{*}{ Sig. } & \multicolumn{2}{|c|}{$\begin{array}{c}\text { Collinierity } \\
\text { Statistics }\end{array}$} \\
\hline & B & Std. Error & & & & Tolerance & VIF \\
\hline Constant & 1,112 & 1,345 & & 0,827 & 0,410 & & \\
\hline LDR & $-0,571$ & 0,217 & $-0,183$ & $-2,631$ & 0,009 & 0,911 & 1,098 \\
\hline NPL & $-0,029$ & 0,064 & $-0,033$ & $-0,447$ & 0,655 & 0,787 & 1,270 \\
\hline DP & 0,145 & 0,064 & 0,180 & 2,282 & 0,024 & 0,708 & 1,413 \\
\hline BOPO & $-0,039$ & 0,673 & $-0,007$ & $-0,058$ & 0,954 & 0,269 & 3,723 \\
\hline ROA & 0,626 & 0,157 & 0,506 & 3,984 & 0,000 & 0,273 & 3,662 \\
\hline
\end{tabular}

Source: analyzed secondary data

From Table 5, the following multiplier linear regression equation can be formulated: $\mathrm{PBV}=1.112-0.571 \mathrm{LDR}-0.029 \mathrm{NPL}+0.145 \mathrm{DP}-$ $0.039 \mathrm{BOPO}+0.626 \mathrm{ROA}+e$

\section{Sobel Test}

Significance test from mediation is conducted using the bootstrapping technique. Mediation effects are known from indirect effects that have significance of less than 0.05. Results of this sobel test on ROA in 
mediating the influence of LDR on PBV sig. is $0.1636>0.05$. Therefore, it can be said that mediation has no effect. Result of this sobel test on ROA in mediating the influence of NPL on PBV sig. is $0.592>0.05$. Hence, it is fair to say that mediation does not have any effect. . Result of this sobel test on ROA in mediating the influence of Income Diversification on PBV sig. is $0.0001<0.05$. Therefore, it can be concluded that mediation has an effect. Result of this sobel test on ROA in mediating the influence of BOPO on PBV sig. is $0.0003<$ 0.05 . Hence, mediation has an effect.

\section{Discussion}

Hypothesis 1, which states that LDR has significantly positive effect on ORA, is accepted. This means that increasing LDR improves gain or ROA. LDR reflects intermediation ability of banks to distribute fund from third parties in the form of credit or loan in order for the banks to make gains, either from interest or profit. Should third party funds are not distributed, they become idle money and cause banks to lose the opportunity to make gains from interests, which means lost profit, that in turn lowers banks' ROA. Results of this research support those of Boadi et al. (2015) and Arif (2012).

Hypothesis 2, which states that NPL has significantly negative effect on ROA, is rejected. Results show that NPL does not have significant negative effect on ROA. The descriptive statistics table shows that NPL's standard deviation is 1.2816 , far lower than mean NPL, sitting at 2.1200, which indicates that NPL variation is small that it does not affect ROA, and is still within the maximum NPL value of $5 \%$. Results of this research are in favor of those of Rodriguez (2014), and Jha and Hui (2012).

Hypothesis 3, which mentions that Income Diversification has significantly positive effect on ROA, is rejected. Results show that Income Diversification does not have significant positive effect on ROA. The descriptive statistics table shows that the standard deviation of Income Diversification is 0.69649, far lower than mean Income Diversification, at 1.0533, which indicates that public banks are still conventional or rely heavily on income from interests. Results of this research agree with those of Wang et al. (2015) and Afza et al. (2008).

Hypothesis 4, which mentions that BOPO has significantly negative effect on ROA, is accepted. This means that the higher the efficiency, as reflected in low BOPO, the higher the profitability or ROA is. Banks with high BOPO ratio do not operate efficiently, as this high ratio describes the high operational cost banks must bear in order to make operational gain. Results of this research are in agreement with those of Bhatia et al. (2012), Almazaril (2014) and Maredza (2014).

Hypothesis 5, which stipulates that LDR has significantly positive effect on PBV, is rejected. Results of this research show that LDR has significantly negative effect on ROA. Mean LDR in this research is $80.0040 \%$ or way above the lower limit of $78 \%$, as required by $\mathrm{BI}$. Increasing $\mathrm{LDR}$ at certain levels improves a company's value, but when this increase is too high, it may lower a company's value as well. High LDR value indicates massive bank credit expansion with relatively limited funding. Hence, there is a risk of liquidity problem. Banking liquidity risk relates to the banks' ability to fulfill its commitments and also collect enough fund at proper levels of prices. Results of this research are in line with those of Gharaibeh (2014) and Waleed et al. (2016).

Hypothesis 6, which stipulates that NPL has significantly negative effect on PBV, is rejected. Results show that NPL does not have significant negative effect on PBV. The 
descriptive statistics table shows that NPL's standard deviation is at 1.2816, far lower than mean NPL, at 2.1200, which indicates that NPL has small variation and does not affect PBV. This means that the lower the NPL, the higher the company value is, as reflected from PBV value. Based on the results of this research, mean NPL value for the $2010-2015$ period is $2.12 \%$, which is far below the limit of $5 \%$. Hence, NPL ratio does not have significantly negative effect on PBV. Results of this research agree with those of Putra (2016), and Rashed Karim and Alam (2013).

Hypothesis 7, which states that Income Diversification has significantly positive effect, is accepted. This shows that the higher the Income Diversification, the higher the company value is, as reflected in PBV value. Income Diversification allows stable profitability for banks as they are free from the risks of interest rate and insolubility (Saunders and Walters, 1994). This fact also agrees with the signal theory that says that Income Diversification relay significantly positive signals to companies. Results of this research support those of Sawada (2013), Afza et al. (2008), Putra (2016), and Chiou et al. (2014).

Hypothesis 8, which states that BOPO has significantly negative effect on $\mathrm{PBV}$, is rejected. The descriptive statistics table shows that BOPO's standard deviation is at 9.43389, far lower than the mean BOPO, at 80.5549, which means that BOPO has little variation that it does not affect PBV. Mean BOPO data for the 2010 - 2015 period is at $80.5549 \%$ or far below the required limit. Therefore, BOPO does not have significantly negative effect on PBV. Results of this research agree with those of Clercq (2015), and Karim and Alam (2013).

Hypothesis 9, stipulates that ROA has significantly positive effect on PBV, is accepted. This shows increasing ROA raises company value, as reflected in PBV value. ROA reflects a company's ability in making profit of the assets used. Mean ROA for the 2010 - 2015 period is $2.1996 \%$ or always more than then best standard at $1.5 \%$. Hence, ROA ratio has significantly positive effect on PBV. Results of this research support those of Chiou et al. (2014), Repi et al. (2015), and Yao and Liang (2005).

Hypothesis 10, which mentions that ROA mediates the effect of LDR on PBV, is rejected. The descriptive statistics table shows that standard deviation ROA is at 1.0909, far lower than mean ROA, at 2.1996, which indicates that ROA has little variation. Hence it cannot mediate the effect of LDR on PBV. The value of direct effect is greater than the indirect effect that ROA role in mediation is weak.

Hypothesis 11, which stipulates that ROA mediates the effect of NPL on PBV, is rejected. The descriptive statistics table shows that standard deviation ROA is at 1.0909, far lower than mean ROA, at 2.1996, which indicates that ROA has little variation. Hence it cannot mediate the effect of NPL on PBV. The value of direct effect is greater than the indirect effect that ROA role in mediation is weak.

Hypothesis 12, which stipulates that ROA mediates the effect of Income Diversification, is accepted. This means that ROA influences the relationship between Income Diversification and PBV. Increasing Income Diversification cannot directly raise company value, but it is influenced by profitability, as reflected in ROA.

Hypothesis 13, which states that ROA mediates the effect of BOPO on PBV, is accepted. This means that ROA affects the relationship between BOPO and PBV. Decreasing BOPO cannot directly raise 
company value, but it is influenced by profitability, as reflected in ROA.

\section{CONCLUSION}

\section{Conclusion}

The hypotheses in this research are aimed at figuring out both their significant and insignificant effect. Results of testing for all hypotheses are given as follow:

(1) Testing on Hypothesis 1 show that LDR variable is partially having significantly positive effect on ROA. Therefore, Hypothesis 1 is accepted.

(2) Testing on Hypothesis 2 show that NPL variable is partially having insignificantly negative effect on ROA. Therefore, Hypothesis 2 is rejected.

(3) Testing on Hypothesis 3 reveal that Income Diversification variable is partially having insignificantly positive effect on ROA. Hence, Hypothesis 3 is rejected.

(4) Testing on Hypothesis 4 reveals that BOPO variable is partially having significantly negative effect on ROA. Hence, Hypothesis 4 is accepted.

(5) Testing on Hypothesis 5 proves that LDR variable is partially having insignificantly negative effect on ROA. Therefore, Hypothesis 5 is rejected.

(6) Testing on Hypothesis 6 proves that NPL variable is partially having insignificantly negative effect on ROA. Therefore, Hypothesis 6 is rejected.

(7) Testing on Hypothesis 7 shows that Income Diversification variable is partially having significantly positive effect on ROA. Hence, Hypothesis 7 is accepted.

(8) Testing on Hypothesis 8 shows that BOPO variable is partially having significantly negative effect on ROA. Hence, Hypothesis 8 is rejected.
(9) Testing on Hypothesis 9 reveals that ROA variable is partially having significantly positive effect on ROA. Therefore, Hypothesis 9 is accepted.

(10) Testing on Hypothesis 10 reveals that ROA does not have any mediation effect on the relationship between LDR variable and PBV. Therefore, Hypothesis 10 is rejected.

(11) Testing on Hypothesis 11 proves that ROA does not have any mediation effect on the relationship between NPL variable and PBV. Hence, Hypothesis 11 is rejected.

(12) Testing on Hypothesis 12 proves that ROA does have mediation effect on the relationship between Income Diversification variable and PBC. Hence, Hypothesis 12 is accepted.

(13) Testing on Hypothesis 13 shows that ROA does have mediation effect on the relationship between BOPO variable and PBV. Therefore, Hypothesis 13 is accepted.

\section{Implication of Managerial Policy}

The management needs to pay attention or control the movement of BOPO, which is the most dominant ratio that affects profitability. Therefore banks need to keep on improving their efficiency in order to gain optimum profit. The management needs to increase Income Diversification, which at the moment is still low, in order to increase profitability and company value. The management has to improve ROA, which is the most important factor affecting company value. ROA reflects a company's ability to make profit from the assets used. Factors affecting ROA must be managed well and risks must be mitigated properly, in order to minimize risks for losses. 


\section{Research Limitation}

This research has some limitations in that it only covers public banks listed in BEI for the 2010 - 2015 period. Moreover, the adjusted R2 value for the second model shows a value of $36 \%$. Therefore, future research must add more variables and more references in order to improve the value of determination coefficient.

\section{Future Research Agenda}

Based on the limitations inherent in the current research, future research must add more variables that may affect company value whilst improving the value of determination coefficient. Moreover, comparisons can also be made between banks in Indonesia and those from regional Asia such as ASEAN, up to those based in Europe.

\section{REFERENCES}

Adnan Gharaibeh, 2014, “Capital Structure Liquidity and Stock Return”, European Scientific Journal, Vol.10, No.25, pp 171-179

Afza, T., Choudhary, S., dan Nazir, M. S, 2008,"Diversification and CorporatePerformance: An Evaluation of Pakistani Firms", South Asian Journal of Management, Vol. 15, No.3, pp.7-18.

Ahmad Waleed, Ahmad Tisman Pasha dan Adeel Akhtar, 2016 "Exploring The Impact of Liquidity on Profitability: Evidence From Banking Sector of Pakistan", Journal of Internet Banking and Comemerce,Vol. 21, No.3.

Ahmed Arif dan Ahmed Nauman Anees, 2012, "Liquidity risk and performance of banking system", Journal of Financial Regulation and Compliance, Vol. 20, No.2, pp. 182-195.

Almazari Ahmad Aref, 2014, "Impact of Internal Factors on Bank Profitability: Comparative Study

between Saudi Arabia and Jordan", Journal of Applied Finance and Banking, Vol.4, No.1, pp.125-140.

Andrew Maredza, 2014, "Internal Determinants Of Bank Profitability In South Africa: Does Bank

Efficiency Matter?", International Business \& Economics Research Journal, Vol.13, No.5, pp.1033-1046.

Aparna Bhatia, Poonam Mahajan dan Subhash Chander, 2012, "Determinants of Profitability of Private sector banks in india," Journal of Commerce and Accounting Research, Vol.1.

Ardian Prima Putra, 2016, "Performance, Diversification, Ownership, Managerial Qualification, and Firm Value of Banking Companies Listed in Indonesia Stock Exchange", Journal of Economics and Sustainable Development Vol.7, No.6, pp.11-20.

Basarir Cagatay dan Ulker Yakup, 2015,"Relationship Between Financial Performance Of Banks and Stock Revenues: Panel Data Analysis", Journal of Applied Finance and Banking, Vol. 5, No.5, pp. 171-183.

Boadi Eric Kofi, Li Yao dan Lartey Victor Curtis, 2016, "Role of Bank Specific, Macroeconomic and Risk Determinants of Banks Profitability: Empirical Evidence from Ghana's Rural Banking Industry", International Journal of Economics and Financial Issues, Vol. 6, No.2, pp. 813-823.

Brigham,E.F. dan J. F. Houston, 2001, Manajemen Keuangan, Jakarta: Erlangga. 
Chandra Teddy, 2007, "Pengaruh Struktur Modal Terhadap Produktivitas Aktiva, Kinerja Keuangan dan Nilai Perusahaan", Arthavidya, Tahun 8 No. 2.

Chavarín, Rubén, 2015, "Determinants of Commercial Bank Profitability in Mexico", EconoQuantum, Vol.12, No.1, pp.51-77.

Chen, Li-Ju dan Chen, Shun-Yu. 2011, “The Influence of Profitability on Firm value with Capital Structure as The Mediator and Firm Size and Industry as Moderators", Investment Management and Financial Innovations,Vol. 8, No. 3, pp. 121-129.

Chen, S., \& Dodd, J. L, 2001, “Operating Income, Residual Income and EVA: Which Metric is More Value Relevant?", Journal of Managerial Issues, Vol. 13, No.1, pp. 65-86.

Chiou, W.J. P., Porter, R. L., \& Sopranzetti, B. J, 2014, “Understanding the Channels of Bank Value Creation During Times of Crisis: Deconstructing ROA", Journal of Accounting and Finance, Vol. 14 No.5, pp. 11-23.

Chiou, W.J. P., Porter, R. L., \& Sopranzetti, B. J, 2014, “Understanding the Channels of Bank Value Creation During Times of Crisis: Deconstructing ROA", Journal of Accounting and Finance, Vol. 14 No.5, pp. 11-23.

Coelli T.J., D.S.P. Rao, C.J. O'Donnell, G.E. Battese, 2005, An Introduction to Efficiency and Productivity Analysis, New York: Springer.

D. Alper dan A. Anbar, 2005, "Bank Specific and Macroeconomic Determinants of Commercial Bank Profitability: Empirical Evidence from Turkey," Business and Economics Research Journal, Vol.2, No.2, pp.139-152.

Feng Wang, Minxue Huang dan Zhigang Shou, 2015, “ Business expansion and firm efficiency in the commercial banking industry: Evidence from the US and China", Asia pacific journal of management Vol. 32, No.2, pp. 551-569.

Ghozali, Imam, 2006, Aplikasi Analisis Multivariate dengan Program SPS, Semarang:. Universitas Diponegoro.

Gilles De Clercq, 2015, "What are the determinants of the franchise value in European banking?", International jornal Vol.5, No.6, pp. 110-121.

Jha Suvita dan Hui, Xiaofeng, 2012 "A comparison of financial performance of commercial banks: A case study of Nepal“, African Journal of Business Management ,Vol.6 No.25, pp. 7601-7611.

Karim Rashed dan Alam Tamima, 2013, "An Evaluation of Financial PeInternational Journal of Trade, Economics and Financerformance of Private Commercial Banks in Bangladesh: Ratio Analysis", Journal of Business Studies Quarterly, Vol. 5, No.2, pp. 65-77.

Kenneth Marangu \& Ambrose Jagongo, 2014, "Price to Book Value Ratio and Financial Statement Variables", Global journals of commerce and management perspective, Vol. 3, pp. 55-56.

Laeven, L. and Levine, R, 2007, "Is There a diversification discount in financial conglomerates?", Journal of Financial Economics, Vol. 85 No. 2, pp. 331-367.

Makram Nouaili1, Ezzeddine Abaoub dan Anis Och, 2015, "The Determinants of Banking Performance in Front of Financial Changes: Case of Trade Banks in Tunisia", International Journal of Economics and Financial Issues, Vol. 5, No.2, pp. 410-417

Malik, Robina et al, 2015, "Bank Peculiar, Macroeconomic Causes and Profitability of Banks: An Evidence from Pakistan", International Journal of Information, Business and Management, Vol. 7, No.4, pp.14-27. 
Michiru Sawada, 2013, “How does the stock market value bank diversification?: empirical evidence from Japanese banks", Pacific Basin Finance Journal, Vol. 25, pp. 40-41.

Ming Li Yao, 2005, "An Investigation into the Differences between the Book Value and Market Value of Commercial Banks: An Empirical Study", International journal of management, Vol. 22, No.1, pp.89-100.

Pandey, I, 2005, Financial Management 9th Edition, New Delhi: KAS Publishing House.

Reilly, F, K. \& Brown, C. K, 1997, Investment Analysis and Portfolio Management. Sixth Edition, The Dryden Press: Fort Worth.

Ruben Chavarin Rodriguez, 2014, “Determinants of Commercial Bank Profitability in Mexico”, Econoquantum Journal, Vol.2, No.1.

S. Repi., S. Murni., D. Adare, 2016, “Faktor Faktor yang Mempengaruhi Nilai Perusahaan Subsektor Perbankan pada BEI dalam Menghadapi MEA", Jurnal EMBA Vol.4 No.1, Hal. 181 -191.

S. Yamuna, 2013, “ Determinants of Profitability in the Banking Sector:A study with special reference to Private Commercial Banks in Sri Lanka," Proceedings of the Third International Symposium, pp.19-24.

Schumpter J, 1939, Business Cycles, New York:McGrawa- Hill.

Shamsudin Norazidah, Mahmood Wan Mansor Wan dan Ismail, Fathiyah, 2013, "The Performance of Stock and the Indicators“,Vol. 4, No.6, pp. 409-413.

Srivastava P, 1999, “Size, Efficiency, and financial reforms in Indian Banking”, Indian Council For Research On International Economic Relations, No. 49 